\title{
Characterization of four new monoclonal antibodies against the distal N-terminal region of PrPc
}

Alessandro Didonna, Anja Colja Venturini, Katrina Hartman, Tanja Vranac, Vladka Čurin Šerbec, Giuseppe Legname

Prion diseases are a group of fatal neurodegenerative disorders that affect humans and animals. They are characterized by the accumulation in the central nervous system of a pathological form of the host-encoded prion protein $\left(\mathrm{PrP}^{\mathrm{C}}\right)$. The prion protein is a membrane glycoprotein that consists of two domains: a globular, structured C-terminus and an unstructured $\mathrm{N}$-terminus. The $\mathrm{N}$-terminal part of the protein is involved in different functions in both health and disease. In the present work we discuss the production and biochemical characterization of a panel of four monoclonal antibodies (mAbs) against the distal N-terminus of $\operatorname{PrP}^{\mathrm{C}}$ using a well-established methodology based on the immunization of $\mathrm{Prnp}^{0 / 0}$ mice. Additionally, we show their ability to block prion ( $\mathrm{PrP}^{\mathrm{sc}}$ ) replication at nanomolar concentrations in a cell culture model of prion infection. These mAbs represent a promising tool for prion diagnostics and for studying the physiological role of the $\mathrm{N}$ terminal domain of PrPC. 
2 Alessandro Didonna ${ }^{1 \# *}$, Anja Colja Venturini2*, Katrina Hartman², Tanja Vranac ${ }^{2}$,

3 Vladka Čurin Šerbec ${ }^{2}$ and Giuseppe Legname ${ }^{1,3 \pi}$

4

$5 \quad{ }^{1}$ Department of Neuroscience, Scuola Internazionale Superiore di Studi Avanzati (SISSA), Trieste, Italy

$6 \quad{ }^{2}$ Department for Production of Diagnostic Reagents and Research, Blood Transfusion Centre of Slovenia, Ljubljana, Slovenia

$7 \quad{ }^{3}$ ELETTRA - Sincrotrone Trieste S.C.p.A, Trieste, Italy.

8 "Current address: Department of Neurology, University of California San Francisco, San Francisco, California, United States of America 9

$10 *$ These authors contributed equally to the work

11

12 'Corresponding author: Giuseppe Legname; SISSA, via Bonomea 265, I-34136 Trieste, Italy; Phone: +39 040 3787 715; E13 mail: giuseppe.legname@sissa.it

14

15

16

17

18

19

20

21

22

23

24

25

26

27

28

29 
32 Introduction

33 Transmissible spongiform encephalopathies (TSEs) are a group of fatal neurodegenerative diseases that

34 occur in human and animals. They can be sporadic, inherited and iatrogenic (Prusiner 1988) and

35 include Creutzfeldt-Jakob disease (CJD), fatal familial insomnia (FFI) and Gerstmann-Straüssler-

36 Scheinker syndrome (GSS) in humans, bovine spongiform encephalopathy (BSE) in cattle, scrapie in

37 sheep and chronic wasting disease (CWD) in deer, moose and elk.

38 The unique agent responsible for these maladies is a pathological conformer $\left(\mathrm{PrP}^{\mathrm{Sc}}\right)$ of the host-

39 encoded prion protein $\left(\mathrm{PrP}^{\mathrm{C}}\right)$. Upon conversion, most $\alpha$-helix motives are replaced by $\beta$-sheet

40 secondary structures (Kuwata et al. 2002; Pan et al. 1993). This event changes dramatically the

41 biochemical properties of $\mathrm{PrP}^{\mathrm{C}}$, which becomes partially resistant to proteases, detergent-insoluble and

42 prone to aggregation (Cohen \& Prusiner 1998).

$43 \mathrm{PrP}^{\mathrm{C}}$ is a ubiquitous glycoprotein expressed mainly in the central nervous system (CNS). It is linked to

44 the cell membrane via a glycosylphospatidylinositol (GPI) anchor, and localized within cholesterol-

45 rich domains called rafts. The physiological role of $\mathrm{PrP}^{\mathrm{C}}$ is still enigmatic; $\operatorname{PrP}^{\mathrm{C}}$-null mice failed to

46 show any gross phenotypic feature (Raeber et al. 1998) and no univocal role has been proposed yet

47 (Didonna 2013).

$48 \mathrm{PrP}^{\mathrm{C}}$ consists of two domains: the globular C-terminus of the protein contains three alpha-helices and

49 an anti-parallel beta-sheet, while the evolutionarily highly conserved N-terminus is flexible and mostly

50 unstructured (Zahn et al. 2000). Despite the lack of ordered structure, many lines of evidence suggest a

51 central role of the $\mathrm{N}$-terminal domain in $\mathrm{PrP}^{\mathrm{C}}$ function.

52 Indeed, the N-terminal part is associated with $\mathrm{PrP}^{\mathrm{C}}$ internalization (Nunziante et al. 2003) for which the

53 initial polybasic region (aa23-aa28 $\mathrm{NH}_{2}$-KKRPKP) was shown to be especially important (Sunyach et

54 al. 2003). The N-terminal domain (aa23-aa90) also acts as a raft-targeting signal, as it is sufficient to

55 confer raft localization when fused to a non-raft transmembrane-anchored protein (Walmsley et al.

56 2003). A recent model suggests that the N-terminus might penetrate the lipid bilayer of the plasma

57 membrane via its polybasic regions and mediate signal transduction within the cytosol (Iraci et al.

58 2014).

59 The N-terminus furthermore binds copper ions through four octapeptide repeats (PHGG(G/S)WGQ;

60 residues aa59-aa90) and its involvement in copper endocytosis and metabolism has been demonstrated 
61 (Brown et al. 1997). Moreover, copper binding seems to promote $\mathrm{PrP}^{\mathrm{C}}$ internalization in clathrin62 coated pits (Hooper et al. 2008). More recently, $\mathrm{PrP}^{\mathrm{C}}$ has been shown to bind $\mathrm{A} \beta$ oligomers with high 63 affinity -possibly mediating their neurotoxic effects- and the polybasic stretch at the extreme N64 terminus is one of the two critical regions for the interaction (Chen et al. 2010; Lauren et al. 2009).

65 Insertions and point mutations in N-terminus impair cell response to oxidative stress, implying that this

66 domain is also required to regulate such cellular activity (Yin et al. 2006; Zeng et al. 2003).

67 Furthermore, N-terminus mediates neuroprotection both in vitro and in vivo (Didonna et al. 2012;

68 Flechsig et al. 2003). Additionally, a recent study has shown that $\operatorname{PrP}^{\mathrm{C}}$ flexible tail regulates the

69 toxicity of globular domain ligands (Sonati et al. 2013).

70 The unstructured domain seems to participate in $\operatorname{PrP}^{\mathrm{Sc}}$ formation as well. The N-terminus has been 71 shown to influence the aggregation of $\operatorname{PrP}$ in vitro by promoting high-order assembled structures 72 (Frankenfield et al. 2005). For instance, the N-terminus has been recently found essential for the 73 assembly of a specific $\beta$-sheet-rich oligomer, containing 12 PrP molecules (Trevitt et al. 2014).

74 Removing the N-terminus decreased the prion conversion efficiency in vivo as well (Supattapone et al.

75 2001). Several inheritable forms of prion diseases are caused by mutations within this region. An

76 increased number of octapeptides correlate with early forms of familial CJDs (Vital et al. 1999) and are

77 shown to increase the rate of protease-resistant PrP formation (Moore et al. 2006). In addition, the

78 polybasic region aa23-aa30 seems crucial for the correct folding of $\mathrm{PrP}^{\mathrm{C}}$ and it might regulate the 79 acquisition of strain-specific conformations in disease (Ostapchenko et al. 2008). Another set of data

80 highlighted the role of the $\mathrm{N}$-terminus in dominant negative inhibition of prion formation. N-terminally

81 truncated $\operatorname{Pr}(\mathrm{Q} 218 \mathrm{~K})$ molecules showed a reduced dominant-negative action compared to full-length

82 forms; the authors propose a model in which the $\mathrm{N}$-terminus domain stabilizes the $\mathrm{C}$-terminus of the

83 molecule (Zulianello et al. 2000).

84 Considering the relevance of the N-terminal domain for the physiopathology of the prion protein, we

85 have generated four monoclonal antibodies that recognize epitopes situated in the distal region of the

86 N-terminus. In this study we present their production and exhaustive characterization, both

87 biochemical and histopathological. A possible use as prion replication inhibitors is also described.

88

89 Materials and Methods

90 Ethics statement 
91 All experiments involving animals were performed in accordance with European regulations [European

92 Community Council Directive, November 24, 1986 (86/609/EEC)]. Experimental procedures were

93 notified to and approved by the Italian Ministry of Health, Directorate General for Animal Health

94 (notification of 17 Sept. 2012). All experiments were approved by the local authority veterinary service

95 and by SISSA Ethics Committee. All reasonable efforts were made to ameliorate suffering. All mice

96 were obtained from the European Mutant Mouse Archive.

97 Approval for research involving human material has been obtained from the Slovenian National

98 Medical Ethics Committee with decision dated January 15, 2008. Post mortem brain tissue of a patient

99 who was clinically suspected for CJD was analyzed by immunohistochemistry without patient's

100 consent because such analysis is obligatory by a ministerial decree in purpose of TSE surveillance

101 (Official Gazette of the Republic of Slovenia, 2/2001). Human brain samples for

102 immunohistochemistry were obtained from the Institute of Pathology, Faculty of Medicine, University

103 of Ljubljana, Slovenia.

104

105 Cell lines and cell culture

106 GT1-1 cells and ScGT1-1 cells (kindly provided by Dr. P. Mellon, The Salk Institute, La Jolla, CA, 107 USA) were maintained in Dulbecco's Modified Eagle's Medium with 4.5 g/l glucose (DMEM)

108 (GIBCO/Invitrogen) supplemented with 10\% v/v fetal bovine serum (FBS) (GIBCO/Invitrogen) and 109 antibiotics (100 IU/mL penicillin and $100 \mu \mathrm{g} / \mathrm{mL}$ streptomycin) (GIBCO/Invitrogen) at $37^{\circ} \mathrm{C}$ in a

110 humidified atmosphere with $5 \% \mathrm{CO}_{2}$.

111 The NS1 murine myeloma cell line and all hybridoma cell lines prepared in this study were maintained

112 in DMEM (ICN Biomedical) supplemented with 13\% v/v bovine serum (HyClone), 2 mM L-glutamine

113 (\#G7513; Sigma), $130 \mu \mathrm{g} / \mathrm{mL}$ streptomycin (Sigma) and $100 \mathrm{IU} / \mathrm{mL}$ penicillin (Sigma).

114

\section{Mouse immunization and cell fusion}

116 Three female Prnp ${ }^{0 / 0}$ mice (6-8 weeks old, mixed C57BL x 129/Sv background) were immunized with

117 full-length (aa23-aa231) oxidized recombinant human prion protein (recHuPrP), with M on codon 129

118 (Prionics, Switzerland). Each mouse was immunized subcutaneously with $20 \mu \mathrm{g}$ of the antigen in

119 Complete Freund's Adjuvant (final volume $200 \mu \mathrm{L}$ ) and then twice in four weeks' intervals

120 intraperitoneally with $20 \mu \mathrm{g}$ of the antigen in Incomplete Freund's Adjuvant (final volume $200 \mu \mathrm{L}$ ). 
121 Mice were bled from the tail vein and the immune sera were collected. They were tested by indirect

122 ELISA and the most responsive animal was given a final booster with $20 \mu \mathrm{g}$ of the antigen in

123 physiological saline (final volume $100 \mu \mathrm{L}$ ), administered intravenously in the tail vein three days prior

124 to cell fusion. Splenocytes were isolated and fused with mouse NS-1 myeloma cells with 50\%

125 polyethylene glycol, according to standard procedures, used in our laboratory. Cell suspension was

126 distributed to 96-well microtiter plates and cultured in $\mathrm{CO}_{2}$ incubator at $37^{\circ} \mathrm{C}$. Hybridoma cells were

127 grown by maintaining the cells for ten days in selective HAT medium and another week in HT medium

128 (DMEM supplemented with hypoxanthine-aminopterin-thymidine or hypoxanthine-thymidine,

129 respectively). The presence of specific antibodies was screened in supernatants during and after 10 to

13014 days by indirect ELISA.

131

132 Indirect enzyme-linked immunosorbent assay (ELISA)

133 Indirect ELISA was performed in 96-well Nunc MaxiSorp microtiter plates (eBioscience). Wells were

134 coated with $0.5 \mu \mathrm{g} / \mathrm{mL}$ of recHuPrP in $50 \mathrm{mM}$ carbonate/bicarbonate buffer, $\mathrm{pH}$ 9.6, and incubated

135 overnight at $4{ }^{\circ} \mathrm{C}$. The next day, the plates were washed three times with washing buffer (sodium

136 phosphate buffer, containing $150 \mathrm{mM} \mathrm{NaCl}, 0.05 \%$ Tween 20, pH 7.2-7.4) and blocked for $30 \mathrm{~min}$ at

$13737^{\circ} \mathrm{C}$ with blocking buffer ( $1 \% \mathrm{BSA}$ in washing buffer). After three washings, the plates were

138 incubated with immune sera, serially diluted $1: 10$, starting dilution $1: 100$, for $1.5 \mathrm{~h}$ at $37^{\circ} \mathrm{C}$. Plates

139 were washed again and then incubated with secondary goat anti-mouse $\operatorname{IgG}+\operatorname{IgM}$ antibodies,

140 conjugated with horseradish peroxidase (HRP) (Jackson Immunoresearch), diluted 1:5,000 in blocking

141 buffer, for $1.5 \mathrm{~h}$ at $37^{\circ} \mathrm{C}$. After washing, substrate 2,2'-azino-bis(3-ethylbenzothiazoline-6-sulfonic

142 acid) (ABTS) (Sigma) in citrate-phosphate buffer, pH 4.5, was added, and incubated for 20 min at 37

$143{ }^{\circ} \mathrm{C}$. The color reaction was measured spectrophotometrically at $405 \mathrm{~nm}$ with a microtiter plate reader.

145 Hybridoma cell lines selection

146 Production of antibodies was monitored and tested for their specificity to recHuPrP with indirect

147 ELISA. Selected hybridomas were cultured in DMEM until stable cell lines were established and then

148 subcloned by limiting dilution. Finally, four monoclonal antibodies were isolated, appropriate cell lines

149 were cultured and then frozen in liquid nitrogen for further use.

150 After culturing cell lines in larger volumes, the supernatants were harvested and monoclonal antibodies

151 purified by fast protein liquid chromatography (AKTA FPLC, GE Healthcare Life Sciences, USA). 
152 Immunoglobulin class and subclass were determined by indirect ELISA using anti-Fc specific 153 antibodies.

154

\section{Epitope mapping}

156 Epitopes were analyzed by PEPSCAN (BV, Netherlands), using overlapping 20-mer synthetic peptides 157 from HuPrP (aa23-aa230), shifted by four amino acids.

158 Afterwards, proposed epitopes were refined with additional overlapping 12-mer synthetic peptides, 159 from N-terminal domain (aa23-aa64 from human PrP and aa44-aa64 from mouse PrP), shifted by three 160 amino acids. For this purpose, peptides were coated to the microtiter plate separately, at concentration $1612 \mu \mathrm{g} / \mathrm{mL}$, incubated with mAbs DE10, DC2, EB8 and EF2 at concentration $5 \mu \mathrm{g} / \mathrm{mL}$ and then 162 incubated with secondary goat anti-mouse IgG+IgM antibodies, conjugated with HRP (Jackson 163 Immunoresearch). Inhibition assays were performed with the same peptides. RecHuPrP was coated to 164 the microtiter plates. Monoclonal antibodies were mixed with 100 times redundant molar peptide 165 166 167 168 169 170 171 172 173 174 concentration. Mixtures were added to microtiter plates and incubated. After washing, plates were incubated with secondary, goat anti-mouse IgG $+\operatorname{IgM}$ antibodies, conjugated with HRP (Jackson Immunoresearch). The percentage of inhibition was calculated.

\section{Western blot analysis}

Different brain homogenates $(10 \% \mathrm{w} / \mathrm{v})$ were prepared from human, bovine, hamster, sheep, deer, rabbit and rat and mouse (BALB/c and $\left.\operatorname{Prnp}^{0 / 0}\right)$ brain tissues in ice-cold buffer ( $0.5 \%$ Nonidet P40, $0.5 \%$ Na-deoxycholate in PBS) with HT 1000 Potter homogenizer. Aliquots were stored at $-80{ }^{\circ} \mathrm{C}$ and centrifuged prior to use ( $5 \mathrm{~min}$ at $5000 \mathrm{x} \mathrm{g}$ ). Samples were loaded on $12 \%$ polyacrylamide gels and SDS-PAGE was performed. Proteins were blotted on $0.2 \mu \mathrm{m}$ nitrocellulose membranes (Bio-Rad) at $200 \mathrm{~mA}$ for $90 \mathrm{~min}$. Membranes were then blocked with 5\% (w/v) non-fat milk in Tris-buffered saline $/ 0.05 \%$ Tween-20 (TBS-T) at $4{ }^{\circ} \mathrm{C}$ overnight, washed in TBS-T and incubated with the four monoclonal antibodies ( $5 \mu \mathrm{g} / \mathrm{mL}$ in 1\% non-fat milk/TBS-T) for $60 \mathrm{~min}$ by shaking at room temperature. Membranes were washed again and incubated for $60 \mathrm{~min}$ with secondary, goat anti-mouse antibodies, conjugated with HRP (Jackson Immunoresearch), in 1\% non-fat milk/TBS-T, at room temperature (RT). Chemiluminescence was detected by ECL kit (Amersham). Films were exposed for $10 \mathrm{~min}$. 
183 Immunohistochemistry (IHC)

184 Sections of paraformaldehyde-fixed, paraffin-embedded human cerebellar tissue samples from a

185 patient with diagnosed sporadic CJD (sCJD) with primitive plaques and synaptic prion deposition

186 pattern were used in the study. Tissue samples were immersed in $96 \%$ formic acid for $1 \mathrm{~h}$ after fixing

187 in paraformaldehyde. Sections were deparaffinized and pretreated for optimal antigen retrieval by 30

188 min autoclaving at $121^{\circ} \mathrm{C}$ in distilled water, followed by a 5 min incubation in $96 \%$ formic acid. The

189 sections were then blocked in 1\% BSA solution for 20 min at RT. They were subsequently incubated

190 overnight at RT in a moist chamber with all N-terminal mAbs tested at the concentration of $5 \mu \mathrm{g} / \mathrm{mL}$.

191 All sections were then washed and incubated for $1.5 \mathrm{~h}$ with anti-mouse HRP-labeled antibodies diluted

192 1:1000 (Jackson ImmunoResearch) at RT. After thorough rinsing, the sections were developed in DAB

193 chromogen (Sigma) for 5 min. Brain tissue counterstaining was obtained by immersion of sections in

194 Mayer's hematoxylin for $2 \mathrm{~min}$.

195

196 Proteinase K digestion assay

197 Cells were washed twice with cold PBS 1X (GIBCO/Invitrogen) and lysed with lysis buffer (10 mM

198 Tris- $\mathrm{HCl} \mathrm{pH} 8.0,150 \mathrm{mM} \mathrm{NaCl}, 0.5 \%$ nonidet P-40 substitute, $0.5 \%$ deoxycholic acid sodium salt) and 199 pelleted by centrifugation at $2300 \mathrm{x}$ g for $5 \mathrm{~min}$. The supernatant was collected and the total protein 200 concentration measured using Bicinchoninic acid assay (Pierce). For the assay, $250 \mu \mathrm{g}$ of protein was 201 treated with $5 \mu \mathrm{g}$ of proteinase K (Roche; ratio protein:protease 50:1) for $1 \mathrm{~h}$ at $37^{\circ} \mathrm{C}$. Digestion was 202 stopped by adding phenylmethyl sulphonyl fluoride (PMSF) (Sigma) to a final concentration of $2 \mathrm{mM}$. 203 PrP was precipitated by ultracentrifugation at 100,000 x g (Optima TL, Beckman, USA) for 1 hour at 4 $204{ }^{\circ} \mathrm{C}$. After centrifugation, the supernatant was discarded and the pellet resuspended in loading buffer 205 before loading onto a 12\% SDS-PAGE. $25 \mu \mathrm{g}$ of total, undigested proteins were loaded as a control. 206 Samples were electroblotted onto membranes of polyvinylidene fluoride (PVDF) (Millipore). After 207 blocking in 5\% non-fat milk protein/TBS-T for $1 \mathrm{~h}$ at RT, membranes were incubated in $1 \mu \mathrm{g} / \mathrm{mL}$ of 208 Fab D18 (InPro Biotechnology, Inc.) in PBS for $2 \mathrm{~h}$ at RT, followed by incubation for $1 \mathrm{~h}$, in the 209 secondary antibody goat-anti-human HRP-conjugated, (Pierce), diluted 1:5000 in 5\% non-fat milk 210 protein/TBS-T. After several washings the signal was detected using ECL kit (Amersham) on ECL 211 Hypermax films (Amersham).

212

\section{ERK1/2 phosphorylation immunoblot}


214 ScGT1 and GT1 cells were treated for 6 days with $\mathrm{mAbs}(5 \mu \mathrm{g} / \mathrm{mL})$ refreshing the medium after 3 days.

215 Cells were then washed twice with cold PBS 1X (GIBCO/Invitrogen) and incubated for $10 \mathrm{~min}$ on ice,

216 in lysis buffer [50 mM Tris- $\mathrm{HCl}(\mathrm{pH} 7.4) 150 \mathrm{mM} \mathrm{NaCl}, 1 \%$ Triton X-100, $2 \mathrm{mM} \mathrm{Na}_{3} \mathrm{VO}_{4}$ and a

217 mixture of protease inhibitors (Roche)]. The cell extracts were then centrifuged at $2300 \mathrm{x} \mathrm{g}$ for $5 \mathrm{~min}$.

218 The supernatant was stored at $-80^{\circ} \mathrm{C}$ prior to use. Total protein concentration was determined using the

219 Bicinchoninic acid assay (Pierce). Twenty-five $\mu \mathrm{g}$ of total proteins was separated by $12 \%$ SDS-PAGE 220 and transferred to PVDF membranes (Millipore). These were then blocked in 5\% non-fat dried milk in

221 TBS-T for $1 \mathrm{~h}$ at RT before overnight incubation at $4^{\circ} \mathrm{C}$ with primary antibodies against ERK (\#9107;

222 Cell Signaling Technology) or phospho-ERK (\#9101; Cell Signaling Technology). After 3 washes in

223 TBS-T, the membranes were incubated for $1 \mathrm{~h}$ at RT in HRP-conjugated secondary antibody (1:2000)

224 (Invitrogen) diluted in blocking solution. The chemiluminescent signal was detected using the ECL kit 225 (Amersham) on ECL Hypermax films (Amersham). Densitometric analysis was performed using a

226 Molecular Imager ChemiDoc XRS System equipped with Quantity One software (Biorad, USA).

\section{Thiazolyl blue tetrazolium bromide (MTT) viability assay}

229 ScGT1 and GT1 cells were incubated in a 96-well, tissue culture-treated plate for 5 days with different

$230 \mathrm{mAbs}$ at concentration $5 \mu \mathrm{g} / \mathrm{mL}$, refreshing medium after 3 days. Then the medium was removed and

231 the cells were incubated with $150 \mu \mathrm{L}$ of MTT (Sigma) working solution $(0.5 \mu \mathrm{g} / \mathrm{mL}$ of MTT in PBS)

232 for $2 \mathrm{~h}$ at $37^{\circ} \mathrm{C}$. The solution was removed and formazan was solubilized by adding $150 \mu \mathrm{L}$ of

233 dimethyl sulfoxide (DMSO) to each well. Optical density was read at $560 \mathrm{~nm}$ and the background

234 subtracted at $670 \mathrm{~nm}$ using the VersaMax plate reader (Molecular Device, USA).

\section{Immunofluorescence assay}

237 ScGT1 and GT1 cells were grown overnight on glass cover slips coated with poly-L-lysine $(10 \mu \mathrm{g} / \mathrm{mL})$ 238 (Sigma) before fixation in 4\% paraformaldehyde in PBS for 20 min at RT. Cells were permeabilized 239 with $0.1 \%$ Triton X-100 in PBS for $10 \mathrm{~min}$ at RT and then treated for $5 \mathrm{~min}$ at RT with 3M Guanidine $240 \mathrm{HCl}$ (Pierce) in PBS. After 3 washes in PBS, cells were blocked for $1 \mathrm{~h}$ at $\mathrm{RT}$ in $5 \%$ normal goat serum 241 (VECTOR Laboratories) in PBS. After blocking, cells were incubated at RT for $2 \mathrm{~h}$ with primary 242 antibody $(5 \mu \mathrm{g} / \mathrm{mL})$ in the same blocking solution. Cells were washed 3 times with PBS and further 243 incubated with secondary antibody conjugated with AlexaFluor 488 (Invitrogen; diluted 1:500 in 244 blocking solution) for $1 \mathrm{~h}$ at RT in the dark. Cells were further washed as described above, before 
245 mounting in Vectashield with DAPI (VECTOR Laboratories). Images were acquired with a DMIR2 246 confocal microscope equipped with Leica Confocal Software (Leica, USA).

\section{Surface plasmon resonance (SPR)}

249 SPR analysis was conducted using the Biacore 2000 biosensor system (GE Healthcare, Pittsburgh).

250 Recombinant MoPrP (200 RU) was immobilized on a CM5 sensor chip (GE Healthcare, Pittsburgh)

251 using standard amine-coupling chemistry. Each mAb was flown over the bound recMoPrP at different

252 concentrations $(0,25,50,100,200$ and $400 \mathrm{nM})$ in HBS-N buffer (10 mM HEPES, $150 \mathrm{mM} \mathrm{NaCl}), \mathrm{pH}$

253 7.4. The association between the antibodies with the immobilized protein was monitored for 4 minutes

254 followed by 10 minutes of dissociation. The results were analyzed using the BIAevaluation software

255 (GE Healthcare, Pittsburgh).

256

257 Results

\section{Monoclonal antibodies production and epitope mapping}

259 To generate PrP-specific mAbs, three Prnp ${ }^{0 / 0}$ mice were immunized with recHuPrP as described in the

260 Materials and Methods section. Two mock injected animals served as negative controls. Mouse sera

261 were tested in serial dilutions by indirect ELISA with recHuPrP coated on 96-well microtiter plates.

262 The detection limit was reached at serum dilutions of $10^{-6}$ for all three animals, suggesting a strong

263 humoral immune response with high antibody titers (Fig. S1). Mouse $m \# 2$ was chosen for splenocyte

264 isolation and cell fusion. A large number of hybridoma cell lines were grown. Cells were selected and

265 cloned according to the reactivity of the mAbs to recHuPrP by ELISA. The antigen used for clone

266 selection was the same as the one used for the immunization of mice. Four cell lines producing mAbs

267 against PrP were identified. The mAbs chosen were designated as DE10, DC2, EB8 and EF2. They

268 were all defined as immunoglobulin subclass IgG2a. Their epitopes were analyzed by direct mapping

269 (Fig. S2, Fig. 1) and inhibition assay (Fig. 2). Suggested epitopes were all at the N-terminal end of the 270 prion protein between aa 26-52 (Fig. 3).

\section{mAbs affinity for PrP}

273 The affinity of each $\mathrm{mAb}$ for recombinant mouse $\operatorname{PrP}(\mathrm{recMoPrP})$ was evaluated by surface plasmon 274 resonance (SPR) analysis as detailed in the Methods section. All mAbs have a high affinity for PrP, in 275 the $\mathrm{nM}$ and sub-nM range (Table 1). Among them, the mAb DC2 exhibited the highest affinity with a 
276 binding affinity constant $\left(\mathrm{K}_{\mathrm{D}}\right)$ equal to $6.14 \times 10^{-10} \mathrm{M}$. The $\mathrm{mAb}$ EB8 instead showed the lowest one

277 with a $\mathrm{K}_{\mathrm{D}}$ of $1.71 \times 10^{-8} \mathrm{M}$.

278

279 mAbs binding to PrP of different species

280 The specificity of the newly generated $\mathrm{mAbs}$ for $\mathrm{PrP}$ was tested by Western blot on brain homogenates

281 from PrP-wild type and knockout mice. All four mAbs recognized the three glycosylated forms of $\operatorname{PrP}^{\mathrm{C}}$

282 (un-, mono- and di-glycosylated) in wild type mouse homogenates but no signal was detected in PrP-

283 knockout samples (Fig. 4).

284 The cross-reactivity of the four mAbs to PrP from other species was assessed too. A panel including

285 human, bovine, hamster, sheep, deer, rabbit and rat brain homogenates was used (Fig. 4). Western blots

286 showed similar binding patterns for all the mAbs on human, hamster and rat PrPs. On the contrary

287 deer, sheep and bovine PrPs were recognized by all mAbs with the exception of EB8. Rabbit PrP was

288 recognized by EF2 and DE10 but not by EB8 and DC2 mAbs (Fig. 4). The presence of an additional

289 glycine residue within the EB8 epitope of deer, sheep, bovine and rabbit PrPs explains the lack of

290 binding of EB8 to these proteins (Fig. 3). Instead the non-synonymous substitution of a glycine with a

291 serine within the DC2 epitope of rabbit PrP explains the lack of binding of DC2 (Fig. 3).

293 Immunoreactivity of the mAbs to $\operatorname{PrPC}^{\mathrm{C}}$ and $\mathrm{PrP}^{\mathrm{Sc}}$ in GT1 cells

294 Once the specificity of the four mAbs was assessed, we tested by immunofluorescence whether they

295 could bind $\mathrm{PrP}^{\mathrm{C}}$ and $\mathrm{PrP}^{\mathrm{Sc}}$ in situ. The mouse hypothalamic GT1-1 cell line, chronically infected with

296 the RML scrapie strain, was used in the screening. Infected (ScGT1) and uninfected (GT1) cells were

297 grown on coverslips and stained as detailed in the Materials and Methods section. PrP localization was

298 investigated by confocal microscopy.

299 The four mAbs were able to stain native PrP in situ, showing similar staining patterns. Specifically, the

300 cell membrane and the perinuclear region were clearly immunostained in GT1 and ScGT1 cells (Fig.

301 5A-5B). Such PrP distribution is consistent with previous reports on GT1 cells (Marijanovic et al.

302 2009). Interestingly, while the perinuclear staining in ScGT1 was more homogeneous around the

303 nucleus, in GT1 cells the staining was more concentrated in one area. At least in uninfected cells, the

304 signal presumably derives from $\operatorname{PrP}^{\mathrm{C}}$ recycling between the cell surface and the endocytic

305 compartment. However, under those experimental conditions we could not ascertain whether the signal

306 coming from infected cells was comprehensive of $\mathrm{PrP}^{\mathrm{Sc}}$ as well. To answer this question, cells were 
307 pre-treated with guanidinium isothiocianate for a few minutes prior to the incubation with mAbs. This

308 chaotropic agent is widely used to denature $\mathrm{PrP}^{\mathrm{Pc}}$ and unmask its buried epitopes (Yamasaki et al.

309 2012). In our case, no relevant changes in PrP staining were appreciated before or after guanidinium

310 treatment (Fig. 5A-5B). Most likely, the distal epitopes recognized by the four mAbs are accessible in

311 both $\mathrm{PrPC}^{\mathrm{C}}$ and $\mathrm{PrP}^{\mathrm{Sc}}$.

312

\section{The use of mAbs in histopathology}

314 After the biochemical characterization, the mAbs were probed for their ability to stain prions in

315 immunohistochemistry experiments, the gold standard for the definitive diagnosis of human prion

316 diseases (Budka et al. 1995). According to the targeted epitope, anti-prion mAbs exhibit different

317 staining patterns. Interestingly, in a study comparing 10 antibodies against epitopes spanning the whole

318 PrP sequence, $\mathrm{N}$-terminus mAbs showed a weaker immunoreactivity compared to antibodies against

319 the midregion of the protein. In addition, while the N-terminus mAbs were able to stain coarser and

320 plaque-type PrP deposits, they stained weakly or not at all fine granular or synaptic deposits (Kovacs et

321 al. 2002).

322 In our tests, cerebellar sections from healthy individuals and from a patient with sporadic CJD were

323 stained according to standard protocols for optimal $\mathrm{PrP}^{\mathrm{Sc}}$ immunodetection in tissue sections (Hegyi I

324 1997). All four mAbs were able to recognize primitive plaques derived from prion deposition in the

325 Purkinje cell layer and in the internal granule cell layer of the SCJD patient (Fig. 6, top panels).

326 Although IHC was performed on consequent slices of cerebellum of the same SCJD case, significant

327 differences in the intensity of mAbs reactions can be observed, probably due to differential exposition

328 of N-terminal epitopes upon pretreatment of the tissue samples. Interestingly, all four mAbs reacted

329 stronger to plaques' rims than their cores. Moreover, consistent with the aforementioned study, prion

330 synaptic deposits were not strongly immunolabeled. This finding might reflect a higher accessibility of

331 the flexible tail of PrP in amyloid states (plaques and plaque-like aggregates) compared to fine deposits

332 (Nakamura et al. 2000).

333

334 Prion replication inhibition

335 Several anti-PrP antibodies have shown the ability to block prion replication if added to the culture

336 media of prion-infected cells (Peretz et al. 2001). Most inhibitory antibodies reported so far recognize

337 epitopes in the C-terminal domain, in particular within the helix $\alpha 1$ (Miyamoto et al. 2005). Thus, we 
338 were particularly keen to test whether our panel of mAbs was able to inhibit prion propagation in

339 ScGT1 cells as well. As preliminary step, we first excluded the possibility that mAbs could exert any

340 cytotoxic effect if incubated with the cells. For this purpose, MTT cell viability assays were performed

341 on both ScGT1 and GT1 cells. All the mAbs were tested at the concentration of $5 \mu \mathrm{g} / \mathrm{mL}$ for 5 days

342 and none of them showed any statistically significant effect on cell viability (Fig. S3).

343 Subsequently, inhibition experiments were carried out by incubating ScGT1 cells with increasing

344 concentrations of purified and sterile $\mathrm{mAbs}(1,2.5,5,7.5 \mu \mathrm{g} / \mathrm{mL})$ for 6 days, refreshing medium on the

345 third day. The levels of $\mathrm{PrPSc}^{\mathrm{Sc}}$ after proteinase $\mathrm{K}$ digestion were used as read-out for the degree of

346 inhibition. The mAbs DE10, DC2 and EF2 promoted a complete clearance of $\mathrm{PrP}^{\mathrm{Sc}}$ signal starting from

$3472.5 \mu \mathrm{g} / \mathrm{mL}$ (Fig. 7). Only EB8 was not able to inhibit prion replication completely, even at the highest

348 concentration tested, although a dramatic decrease of $\mathrm{PrP}^{\mathrm{Sc}}$ was observed at higher concentrations (Fig. 349 7).

350 To assess if the prion replication inhibition was a stable or transitory phenomenon a time-course

351 experiment was conducted. ScGT1 cells were treated for one week with the different mAbs at the

352 concentration of $5 \mu \mathrm{g} / \mathrm{mL}$. The antibodies were subsequently removed from the media and the cells

353 were cultured for an additional month, checking the levels of PrPsc every week by PK digestion. All

354 the antibodies showed a stable effect over time, since no appreciable come-back of $\mathrm{PrP}^{\mathrm{Sc}}$ was detected

355 in the 4 weeks after the treatment (Fig. 8).

356

357 ERK pathway analysis upon mAbs treatment

$358 \mathrm{PrP}^{\mathrm{C}}$ can trigger signals inside the cytosol when clustered on the cell membrane (Mouillet-Richard et 359 al. 2000). Among the different pathways, $\operatorname{PrP}^{\mathrm{C}}$ was shown to modulate the extracellular regulated 360 kinase (ERK) 1/2 cascade either in neuronal or non-neuronal cells (Schneider et al. 2003). Indeed, 361 prion infection was demonstrated to aberrantly increase the levels of the ERK complex in its active 362 form both in vitro and in vivo (Didonna \& Legname 2010; Lee et al. 2005). Thus, we tested whether $363 \mathrm{mAb}$-treatment could not only block prion infection, but also reset the ERK pathway to healthy levels.

364 To this purpose, both infected and uninfected GT1 cells were incubated with the four mAbs for six 365 days at the final concentration of $5 \mu \mathrm{g} / \mathrm{mL}$, and total cytosolic extracts were tested for phospho-ERK

366 levels by Western blot (Fig. 9). Surprisingly, although the mAb treatment cleared prions, it did not

367 revert ERK activation to the original state but, on the contrary, it further enhanced ERK

368 phosphorylation (at least for the mAbs DE10, DC2 and EB8). Interestingly, the treatment of uninfected 
369 cells did not increase the levels of phospho-ERK and in the case of mAb DC2, ERK activation was 370 significantly reduced.

\section{Discussion}

373 Antibodies are an invaluable tool in prion biology. Since the formulation of the "protein only"

374 hypothesis, a plethora of antibodies have been raised against different epitopes of $\mathrm{PrPC}^{\mathrm{C}}$, and they

375 helped shed light on the structure and function of the prion protein. However, the largest part of the 376 commercially available antibodies targets the globular and central domains of $\mathrm{PrP}^{\mathrm{C}}$, probably as a 377 consequence of using the proteolytic product $\mathrm{PrP}^{27-30}$ as immuno-antigen. Even in a recent systematic 378 attempt to develop a more comprehensive panel of antibodies spanning the whole $\mathrm{PrP}^{\mathrm{C}}$ sequence, most 379 epitopes recognized in the N-terminal domain were located within the octapeptide repeats, with the 380 exclusion of the very distal portion (Polymenidou et al. 2008).

381 Here, we report the production and the exhaustive characterization of four novel monoclonal antibodies 382 which recognize three epitopes in the first 50 amino acids of the $\mathrm{PrP}^{\mathrm{C}}$ mature sequence, designated 383 DE10, DC2, EB8 and EF2. The mAbs were raised against recombinant human $\operatorname{PrP}(\operatorname{recHuPrP} 23-231)$ 384 in $\mathrm{PrP}^{\mathrm{C}}$-deficient mice and recognize PrP from different species. It is curious how only N-terminal 385 mAbs were obtained, although mice were immunized with full-length PrP and also the selection of cell 386 lines was performed with the same antigene. As $\operatorname{Prnp}^{0 / 0} \mathrm{~B}$ cells were fused to Prnp ${ }^{+/+}$NS1 myeloma 387 cells, one possible explanation could be that Abs to other PrP epitopes might have elicited apoptotic 388 signals upon binding to $\mathrm{PrP}^{\mathrm{C}}$ on hybridoma cells. Thus only non-toxic mAbs could have been 389 spontaneously selected.

390 Several lines of evidence suggest that the three epitopes recognized by our panel of mAbs are linear 391 and continuous. First, peptide array analysis univocally mapped the three epitopes in the distant N392 terminus of PrP without any signal coming from other portions of the protein. Second, the mAbs are 393 able to detect PrP in western blot assays performed in denaturing conditions. Lastly, in situ binding to

394 PrP on the cell surface survived the treatment with guanidinium - a strong chaotropic agent. However, a 395 recent work has highlighted how some discontinuous epitopes in PrP can remain functional following 396 denaturing treatments due to a quick refolding in a structure still amenable to be recognized by 397 conformation-dependent antibodies (Kang et al. 2012). Thus, the existence of conformational epitopes 398 cannot be formally excluded. To systematically address this question, further studies employing the 399 latest high-resolution mapping technologies will be required. For instance, mutational scanning by cell- 
400 surface display and single-molecule real-time (SMRT) deep sequencing have been recently used to

401 identify discontinuous residues critical to ligand binding for four anti-PrP antibodies (Doolan \& Colby 402 2015).

403 Interestingly, all mAbs belong to immunoglobulin subclass IgG2a. The production of Ig2a antibodies is 404 one of the characteristics of the Th1 type immune response (Mosmann et al. 1986). It has been shown 405 that prion conformation significantly influences the type of immune response in Prnp $^{0 / 0}$ mice (Khalili406 Shirazi et al. 2005). We could speculate that the structure acquired by recombinant HuPrP in our 407 immunization experiments might have shifted the immune response toward a Th1 type.

408 Besides their intuitive usage in diagnostics and basic research for investigating the role of the N409 terminus in prion protein physiology, we were also interested in possible therapeutic applications to 410 treat prion disorders. To date, hundreds of chemical compounds have been found to stop prion 411 replication in vitro or in cell cultures (Sim \& Caughey 2009) but very little success was achieved in 412 translating their properties to in vivo models, mainly due to their toxicity or inability to cross the blood 413 brain barrier (Chang et al. 2012).

414 Antibodies are one of the most promising tools in developing effective cures for prion diseases (Rovis 415 \& Legname 2014). Indeed, they have been shown to clear prion infectivity in cellular models of prion 416 replication (Peretz et al. 2001) and to significantly delay the disease development in mice if mAbs are 417 administered shortly after infection (White et al. 2003).

418 Several mechanisms have been proposed to explain antibody-mediated prion replication inhibition.

419 Anti-PrP antibodies may slow down the conversion process by preventing interaction between $\mathrm{PrP}^{\mathrm{C}}$ 420 and $\mathrm{PrP}^{\mathrm{Sc}}$, as the latter is believed to act as a template to refold $\mathrm{PrP}^{\mathrm{C}}$ into new molecules of the 421 pathological conformer (Peretz et al. 2001). Alternatively, antibodies may indirectly affect prion 422 conversion through perturbation of $\operatorname{PrP}^{\mathrm{C}}$ cellular trafficking (Feraudet et al. 2005). Finally, it has been 423 suggested that anti-PrP antibodies can block $\mathrm{PrP}^{\mathrm{Sc}}$ replication by accelerating $\mathrm{PrP}^{\mathrm{C}}$ degradation (Perrier 424 et al. 2004).

425 In our inhibition experiments, three of the four mAbs (DC2, DE10 and EF2) -whose epitopes span the 426 aa35-aa52 region- were able to lower prion conversion below the detection limit of Western blot at $\mathrm{nM}$ 427 concentrations. Moreover, the inhibition resulted stable over time as pulse-chase experiments with a 428 one-month follow-up did not show any increase in $\mathrm{PrP}^{\mathrm{Sc}}$ levels after incubation with the antibodies. 429 Three regions within the $\operatorname{PrP}^{\mathrm{C}}$ molecule (aa23-aa33, aa98-aa110 and aa136-aa158) have been shown to 430 tightly bind $\mathrm{PrP}^{\mathrm{Sc}}$ and mediate prion conversion (Solforosi et al. 2007). The epitopes recognized by our 
431 mAbs are adjacent to the region aa23-aa33, which corresponds to the polybasic domain. This may

432 explain their high efficiency in blocking prion replication. Moreover, a novel $\mathrm{PrP}^{\mathrm{Sc}}$-specific epitope has

433 been recently reported in the region aa31-aa47 by using $\mathrm{mAbs}$ raised against intact $\mathrm{PrP}^{\mathrm{Sc}}$ complexes

434 (Masujin et al. 2013).

435 Surprisingly, in our panel, mAb EB8 failed to promote prion clearance as efficiently as the other

436 antibodies. Since its epitope (aa26-aa34) almost overlaps with the polybasic region we expected better

437 performances, as the domain is one of the three replicative interfaces and it was found playing a critical

438 role in prion conversion in vivo (Solforosi et al. 2007; Turnbaugh et al. 2012). This observation could

439 be ascribed to the lower affinity of EB8 compared to the other mAbs as highlighted by SPR assays. In

440 addition, it should be mentioned that an independent antibody recognizing the same epitope in ovine

441 PrP showed results comparable to EB8 in a large inhibition screening on 145 antibodies (Feraudet et al. 442 2005).

443 Little is known about how prions mediate toxic signals to the cell. Prion infection was demonstrated to 444 aberrantly increase the levels of the ERK complex in its active form both in vitro and in vivo (Didonna 445 \& Legname 2010; Lee et al. 2005). We have previously demonstrated that the Fab fragment D18 does 446 not revert ERK activation although it is very efficient in clearing prions (Didonna \& Legname 2010).

447 D18 epitope spans from residues 132-156 in the globular domain of PrP. Thus we asked if antibodies 448 targeting the N-terminal domain were better at decreasing the levels of phospho-ERK in ScGT1 cells.

449 Unfortunately, our data show that ERK activation was even enhanced upon addition of mAbs to 450 infected GT1 cells. This finding suggests that the targeted epitope is irrelevant as prion infection might 451 have irremediably altered cell physiology. Alternatively, we could speculate that antibody treatment 452 does not fully block prion replication but resets the process at levels below the limit of detection.

\section{Conclusions}

455 In summary, by combining a variety of techniques we have described a new panel of antibodies that 456 will be useful in both basic research and diagnostics. Moreover, we have identified three of them as 457 promising candidates for immunotherapy of prion diseases. Future studies will aim to assess their 458 safety upon in vivo administration. Since antibodies cannot cross the blood brain barrier, the next step 459 will be converting the mAbs into single-chain variable fragments ( $\mathrm{scFvs}$ ). scFvs are monovalent mini460 antibodies maintaining the same antigen specificity of mAbs that can be easily engineered to be 461 expressed by adeno-associate viral (AAV) vectors for intracerebral delivery (Campana et al. 2009). 
462 Indeed, a similar approach using AAV serotypes 2 and 9 to deliver several anti-PrP scFvs delayed the 463 onset of prion pathogenesis in mice without fully blocking it (Moda et al. 2012; Wuertzer et al. 2008).

464 Alternatively, scFvs can be fused to a cell-penetrating peptide, which can cross the blood-brain barrier 465 and deliver mini-antibodies to the site of action ( $\mathrm{Skrlj}$ et al. 2013). It will be important to assess if 466 scFvs against N-terminal epitopes are more effective in stopping prion replication compared to those 467 targeting the globular domain.

468 In order to encourage the use of these novel mAbs through collaborative or independent projects, the 469 relative hybridoma cell lines are available for the prion research community in the cell bank at the 470 Blood Transfusion Center of Slovenia (http://www.ztm.si/en/).

References

Brown DR, Qin K, Herms JW, Madlung A, Manson J, Strome R, Fraser PE, Kruck T, von Bohlen A, Schulz-Schaeffer W, Giese A, Westaway D, and Kretzschmar H. 1997. The cellular prion protein binds copper in vivo. Nature 390:684-687.

Budka H, Aguzzi A, Brown P, Brucher JM, Bugiani O, Gullotta F, Haltia M, Hauw JJ, Ironside JW, Jellinger K, and et al. 1995. Neuropathological diagnostic criteria for Creutzfeldt-Jakob disease (CJD) and other human spongiform encephalopathies (prion diseases). Brain Pathol 5:459-466.

Campana V, Zentilin L, Mirabile I, Kranjc A, Casanova P, Giacca M, Prusiner SB, Legname G, and Zurzolo C. 2009. Development of antibody fragments for immunotherapy of prion diseases. Biochem J 418:507-515.

Chang B, Petersen R, Wisniewski T, and Rubenstein R. 2012. Influence of Mabs on PrP(Sc) formation using in vitro and cell-free systems. PLoS One 7:e41626.

Chen S, Yadav SP, and Surewicz WK. 2010. Interaction between human prion protein and amyloidbeta (Abeta) oligomers: role OF N-terminal residues. J Biol Chem 285:26377-26383.

Cohen FE, and Prusiner SB. 1998. Pathologic conformations of prion proteins. Annu Rev Biochem 67:793-819.

Didonna A. 2013. Prion protein and its role in signal transduction. Cell Mol Biol Lett 18:209-230.

Didonna A, and Legname G. 2010. Aberrant ERK 1/2 complex activation and localization in scrapieinfected GT1-1 cells. Mol Neurodegener 5:29.

Didonna A, Sussman J, Benetti F, and Legname G. 2012. The role of Bax and caspase-3 in doppelinduced apoptosis of cerebellar granule cells. Prion 6:309-316.

Doolan KM, and Colby DW. 2015. Conformation-dependent epitopes recognized by prion protein antibodies probed using mutational scanning and deep sequencing. $J$ Mol Biol 427:328-340.

Feraudet C, Morel N, Simon S, Volland H, Frobert Y, Creminon C, Vilette D, Lehmann S, and Grassi J. 2005. Screening of 145 anti-PrP monoclonal antibodies for their capacity to inhibit PrPSc replication in infected cells. J Biol Chem 280:11247-11258.

Flechsig E, Hegyi I, Leimeroth R, Zuniga A, Rossi D, Cozzio A, Schwarz P, Rulicke T, Gotz J, Aguzzi A, and Weissmann C. 2003. Expression of truncated PrP targeted to Purkinje cells of PrP knockout mice causes Purkinje cell death and ataxia. EMBO J 22:3095-3101. 
502 Frankenfield KN, Powers ET, and Kelly JW. 2005. Influence of the N-terminal domain on the

503

504

505

506

507

508

509

510

511

512

513

514

515

516

517

518

519

520

521

522

523

524

525

526

527

528

529

530

531

532

533

534

535

536

537

538

539

540

541

542

543

544

545

546

547 aggregation properties of the prion protein. Protein Sci 14:2154-2166.

Hegyi I HJ, Flicker H, Ironside J, Hauw JJ, Tateishi J, Haltia M, Bugiani O, Aguzzi A, Budka H. 1997. Prion protein immunocytochemistry: reliable staining protocol, immunomorphology, and diagnostic pitfalls. Clinical Neuropathology 16:262-263.

Hooper NM, Taylor DR, and Watt NT. 2008. Mechanism of the metal-mediated endocytosis of the prion protein. Biochem Soc Trans 36:1272-1276.

Iraci N, Stincardini C, Barreca ML, and Biasini E. 2014. Decoding the Function of the N-Terminal Tail of the Cellular Prion Protein to Inspire Novel Therapeutic Avenues for Neurodegenerative Diseases. Virus Res Published online 23 October.

Kang HE, Weng CC, Saijo E, Saylor V, Bian J, Kim S, Ramos L, Angers R, Langenfeld K, Khaychuk V, Calvi C, Bartz J, Hunter N, and Telling GC. 2012. Characterization of conformationdependent prion protein epitopes. J Biol Chem 287:37219-37232.

Khalili-Shirazi A, Quaratino S, Londei M, Summers L, Tayebi M, Clarke AR, Hawke SH, Jackson GS, and Collinge J. 2005. Protein conformation significantly influences immune responses to prion protein. J Immunol 174:3256-3263.

Kovacs GG, Head MW, Hegyi I, Bunn TJ, Flicker H, Hainfellner JA, McCardle L, Laszlo L, Jarius C, Ironside JW, and Budka H. 2002. Immunohistochemistry for the prion protein: comparison of different monoclonal antibodies in human prion disease subtypes. Brain Pathol 12:1-11.

Kuwata K, Li H, Yamada H, Legname G, Prusiner SB, Akasaka K, and James TL. 2002. Locally disordered conformer of the hamster prion protein: a crucial intermediate to PrPSc? Biochemistry 41:12277-12283.

Lauren J, Gimbel DA, Nygaard HB, Gilbert JW, and Strittmatter SM. 2009. Cellular prion protein mediates impairment of synaptic plasticity by amyloid-beta oligomers. Nature 457:1128-1132.

Lee CC, Kuo LT, Wang CH, Scaravilli F, and An SF. 2005. Accumulation of prion protein in the peripheral nervous system in human prion diseases. $J$ Neuropathol Exp Neurol 64:716-721.

Marijanovic Z, Caputo A, Campana V, and Zurzolo C. 2009. Identification of an intracellular site of prion conversion. PLoS Pathog 5:e1000426.

Masujin K, Kaku-Ushiki Y, Miwa R, Okada H, Shimizu Y, Kasai K, Matsuura Y, and Yokoyama T. 2013. The N-terminal sequence of prion protein consists an epitope specific to the abnormal isoform of prion protein (PrP(Sc)). PLoS One 8:e58013.

Miyamoto K, Nakamura N, Aosasa M, Nishida N, Yokoyama T, Horiuchi H, Furusawa S, and Matsuda H. 2005. Inhibition of prion propagation in scrapie-infected mouse neuroblastoma cell lines using mouse monoclonal antibodies against prion protein. Biochem Biophys Res Commun 335:197-204.

Moda F, Vimercati C, Campagnani I, Ruggerone M, Giaccone G, Morbin M, Zentilin L, Giacca M, Zucca I, Legname G, and Tagliavini F. 2012. Brain delivery of AAV9 expressing an anti-PrP monovalent antibody delays prion disease in mice. Prion 6:383-390.

Moore RA, Herzog C, Errett J, Kocisko DA, Arnold KM, Hayes SF, and Priola SA. 2006. Octapeptide repeat insertions increase the rate of protease-resistant prion protein formation. Protein Sci 15:609-619.

Mosmann TR, Cherwinski H, Bond MW, Giedlin MA, and Coffman RL. 1986. Two types of murine helper T cell clone. I. Definition according to profiles of lymphokine activities and secreted proteins. J Immunol 136:2348-2357.

Mouillet-Richard S, Ermonval M, Chebassier C, Laplanche JL, Lehmann S, Launay JM, and Kellermann O. 2000. Signal transduction through prion protein. Science 289:1925-1928. 
Nakamura S, Ono F, Hamano M, Odagiri K, Kubo M, Komatsuzaki K, Terao K, Shinagawa M, Takahashi K, and Yoshikawa Y. 2000. Immunohistochemical detection of apolipoprotein E within prion-associated lesions in squirrel monkey brains. Acta Neuropathol 100:365-370.

Nunziante M, Gilch S, and Schatzl HM. 2003. Essential role of the prion protein N terminus in subcellular trafficking and half-life of cellular prion protein. J Biol Chem 278:3726-3734.

Ostapchenko VG, Makarava N, Savtchenko R, and Baskakov IV. 2008. The polybasic N-terminal region of the prion protein controls the physical properties of both the cellular and fibrillar forms of PrP. J Mol Biol 383:1210-1224.

Pan KM, Baldwin M, Nguyen J, Gasset M, Serban A, Groth D, Mehlhorn I, Huang Z, Fletterick RJ, Cohen FE, and et al. 1993. Conversion of alpha-helices into beta-sheets features in the formation of the scrapie prion proteins. Proc Natl Acad Sci U S A 90:10962-10966.

Peretz D, Williamson RA, Kaneko K, Vergara J, Leclerc E, Schmitt-Ulms G, Mehlhorn IR, Legname G, Wormald MR, Rudd PM, Dwek RA, Burton DR, and Prusiner SB. 2001. Antibodies inhibit prion propagation and clear cell cultures of prion infectivity. Nature 412:739-743.

Perrier V, Solassol J, Crozet C, Frobert Y, Mourton-Gilles C, Grassi J, and Lehmann S. 2004. Anti-PrP antibodies block PrPSc replication in prion-infected cell cultures by accelerating PrPC degradation. J Neurochem 89:454-463.

Polymenidou M, Moos R, Scott M, Sigurdson C, Shi YZ, Yajima B, Hafner-Bratkovic I, Jerala R, Hornemann S, Wuthrich K, Bellon A, Vey M, Garen G, James MN, Kav N, and Aguzzi A. 2008. The POM monoclonals: a comprehensive set of antibodies to non-overlapping prion protein epitopes. PLoS One 3:e3872.

Prusiner SB. 1988. Molecular structure, biology, and genetics of prions. Adv Virus Res 35:83-136.

Raeber AJ, Brandner S, Klein MA, Benninger Y, Musahl C, Frigg R, Roeckl C, Fischer MB, Weissmann C, and Aguzzi A. 1998. Transgenic and knockout mice in research on prion diseases. Brain Pathol 8:715-733.

Rovis TL, and Legname G. 2014. Prion Protein-Specific Antibodies-Development, Modes of Action and Therapeutics Application. Viruses 6:3719-3737.

Schneider B, Mutel V, Pietri M, Ermonval M, Mouillet-Richard S, and Kellermann O. 2003. NADPH oxidase and extracellular regulated kinases $1 / 2$ are targets of prion protein signaling in neuronal and nonneuronal cells. Proc Natl Acad Sci U S A 100:13326-13331.

Sim VL, and Caughey B. 2009. Recent advances in prion chemotherapeutics. Infect Disord Drug Targets 9:81-91.

Skrlj N, Drevensek G, Hudoklin S, Romih R, Curin Serbec V, and Dolinar M. 2013. Recombinant single-chain antibody with the Trojan peptide penetratin positioned in the linker region enables cargo transfer across the blood-brain barrier. Appl Biochem Biotechnol 169:159-169.

Solforosi L, Bellon A, Schaller M, Cruite JT, Abalos GC, and Williamson RA. 2007. Toward molecular dissection of PrPC-PrPSc interactions. J Biol Chem 282:7465-7471.

Sonati T, Reimann RR, Falsig J, Baral PK, O'Connor T, Hornemann S, Yaganoglu S, Li B, Herrmann US, Wieland B, Swayampakula M, Rahman MH, Das D, Kav N, Riek R, Liberski PP, James $\mathrm{MN}$, and Aguzzi A. 2013. The toxicity of antiprion antibodies is mediated by the flexible tail of the prion protein. Nature 501:102-106.

Sunyach C, Jen A, Deng J, Fitzgerald KT, Frobert Y, Grassi J, McCaffrey MW, and Morris R. 2003. The mechanism of internalization of glycosylphosphatidylinositol-anchored prion protein. EMBO J 22:3591-3601.

Supattapone S, Muramoto T, Legname G, Mehlhorn I, Cohen FE, DeArmond SJ, Prusiner SB, and Scott MR. 2001. Identification of two prion protein regions that modify scrapie incubation time. J Virol 75:1408-1413. 
Trevitt CR, Hosszu LL, Batchelor M, Panico S, Terry C, Nicoll AJ, Risse E, Taylor WA, Sandberg MK, Al-Doujaily H, Linehan JM, Saibil HR, Scott DJ, Collinge J, Waltho JP, and Clarke AR. 2014. N-terminal domain of prion protein directs its oligomeric association. J Biol Chem 289:25497-25508.

Turnbaugh JA, Unterberger U, Saa P, Massignan T, Fluharty BR, Bowman FP, Miller MB, Supattapone S, Biasini E, and Harris DA. 2012. The N-terminal, polybasic region of $\operatorname{PrP}(\mathrm{C})$ dictates the efficiency of prion propagation by binding to $\operatorname{PrP}(\mathrm{Sc})$. J Neurosci 32:8817-8830.

Vital C, Gray F, Vital A, Ferrer X, and Julien J. 1999. Prion disease with octapeptide repeat insertion. Clin Exp Pathol 47:153-159.

Walmsley AR, Zeng F, and Hooper NM. 2003. The N-terminal region of the prion protein ectodomain contains a lipid raft targeting determinant. J Biol Chem 278:37241-37248.

White AR, Enever P, Tayebi M, Mushens R, Linehan J, Brandner S, Anstee D, Collinge J, and Hawke S. 2003. Monoclonal antibodies inhibit prion replication and delay the development of prion disease. Nature 422:80-83.

Wuertzer CA, Sullivan MA, Qiu X, and Federoff HJ. 2008. CNS delivery of vectored prion-specific single-chain antibodies delays disease onset. Mol Ther 16:481-486.

Yamasaki T, Suzuki A, Shimizu T, Watarai M, Hasebe R, and Horiuchi M. 2012. Characterization of intracellular localization of $\operatorname{PrP}(\mathrm{Sc})$ in prion-infected cells using a $\mathrm{mAb}$ that recognizes the region consisting of aa 119-127 of mouse PrP. J Gen Virol 93:668-680.

Yin S, Yu S, Li C, Wong P, Chang B, Xiao F, Kang SC, Yan H, Xiao G, Grassi J, Tien P, and Sy MS. 2006. Prion proteins with insertion mutations have altered N-terminal conformation and increased ligand binding activity and are more susceptible to oxidative attack. $J$ Biol Chem 281:10698-10705.

Zahn R, Liu A, Luhrs T, Riek R, von Schroetter C, Lopez Garcia F, Billeter M, Calzolai L, Wider G, and Wuthrich K. 2000. NMR solution structure of the human prion protein. Proc Natl Acad Sci U $A$ A7:145-150.

Zeng F, Watt NT, Walmsley AR, and Hooper NM. 2003. Tethering the N-terminus of the prion protein compromises the cellular response to oxidative stress. J Neurochem 84:480-490.

Zulianello L, Kaneko K, Scott M, Erpel S, Han D, Cohen FE, and Prusiner SB. 2000. Dominantnegative inhibition of prion formation diminished by deletion mutagenesis of the prion protein. J Virol 74:4351-4360. 


\section{Figure Legends}

646 Figure 1. Epitope mapping of $\mathbf{m A b s}$ through direct binding.

647 Synthesized peptides from $\operatorname{HuPrP}(1$ to 11$)$ and $\operatorname{MoPrP}(12$ to15) were coated to the microplates at 648 concentration $2 \mu \mathrm{g} / \mathrm{mL}$. A detailed description of the peptides used in this assay is provided in 649 Supplemental Figure S2. The four monoclonal antibodies DE10, DC2, EB8 and EF2 were added in 650 concentration $5 \mu \mathrm{g} / \mathrm{mL}$. Bars indicate binding of antibodies to peptides.

\section{Figure 2. Epitope mapping of mAbs through competitive ELISA.}

$653 \operatorname{RecHuPrP}(5 \mu \mathrm{g} / \mathrm{mL})$ was coated to $96-w e l l$ microtiter plate as antigen. Mixtures of the four 654 monoclonal antibodies ( $1 \mu \mathrm{g} / \mathrm{mL}$ for EB8 and $0.2 \mu \mathrm{g} / \mathrm{mL}$ for the others) and synthesized peptides from $655 \mathrm{HuPrP}$ (1 to 11$)$ and $\operatorname{MoPrP}(12$ to 15$)(0.8 \mu \mathrm{g} / \mathrm{mL})$ were added. A detailed description of the peptides used in this assay is provided in Supplemental Figure S2. Bars indicate inhibition of monoclonal antibodies' binding.

Figure 3. Suggested epitopes for the four monoclonal antibodies based on direct mapping and competitive ELISA essay.

661 The epitopes recognized by the 4 four mAbs (26-34aa for EB8; 35-46aa for DC2; 44-52aa for DE10 662 and 47-52 for EF2) are highlighted in a multi-alignment among the amino acidic $\mathrm{N}$-terminal sequences

663 of mature PrP from the following species: human (Homo sapiens; P04156), mouse (Mus musculus;

664 P04925), golden hamster (Mesocricetus auratus; P04273), sheep (Ovis aries; P23907), cow (Bos 665 taurus; P10279), red deer (Cervus elaphus; P67987), rat (Rattus norvegicus; $\underline{\mathrm{P} 13852)}$ ) and rabbit 666 (Oryctolagus cuniculus; Q95211). 
668 Figure 4. Immunoreactivity of mAbs probed by Western blot.

669 Homogenates from human $(\mathrm{Hu})$, bovine (Bo), hamster (Ha), sheep (Sh), deer (De), rabbit (Ra), rat 670 (Rat), mouse (Mo) and $\operatorname{Prnp}^{0 / 0}$ mouse (koMo) brain tissues were analyzed by Western blot using the 671 four monoclonal antibodies. Different pattern of detection were observed. Samples from human, 672 hamster, rat and mouse tissues were consistently detected by all the mAbs while bovine, sheep, deer 673 and rabbit samples were poorly recognized by the EB8 antibody. Rabbit PrP was not detected by DC2 antibody. Non-contiguous lanes are highlighted (white lines).

676 Figure 5. Immunolocalization of PrP in GT1 cells.

677 GT1 (panel A) and ScGT1 (panel B) cells were fixed with PFA and PrP was immunostained with the 678 four mAbs (in green) as detailed in Materials and Methods. Nuclei were counterstained with DAPI (in 679 blue). On the left of each panel merged images are shown. All the antibodies show a similar pattern.

680 The cell membrane and the perinuclear region are stained. No difference was observed after 681 guanidinium treatment. Images are representative of at least three coverslips. Scale bars, $20 \mu \mathrm{m}$.

Figure 6. Immunohistochemistry on human tissue samples.

684 Immunohistochemistry of $\mathrm{PrP}^{\mathrm{Sc}}$ deposits in the cerebellum of a sCJD patient (upper four figures) and 685 of a non-CJD control (lower four figures). Immunolabeling was performed with $5 \mu \mathrm{g} / \mathrm{mL}$ of mAbs 686 EB8, DC2, DE10 or EF2, respectively. Magnified: 200 x.

688 Figure 7. N-terminal mAbs can inhibit prion replication.

689 RML infected GT1 cells were treated for 6 days with increasing concentrations $(0,1,2.5,5$ and 7.5 $690 \mu \mathrm{g} / \mathrm{mL}$ ) of EB8, DE10, DC2 and EF2 mAbs, refreshing medium the third day. Cell lysate were 691 digested with proteinase $\mathrm{K}\left(\mathrm{PK}+\right.$ lanes) and $\mathrm{PrP}^{\mathrm{Sc}}$ levels checked by Western blot using Fab D18 for 692 detection. As positive control (PC) cell lysates from uninfected GT1 cells were also digested. About 25 $693 \mu \mathrm{g}$ of total protein were loaded as control (PK - lanes). DE10, DC2 and EF2 mAbs promoted a

694 complete clearance of prions starting from the lowest concentration tested whilst cells treated with EB8 695 showed a residual signal of $\mathrm{PrP}^{\mathrm{Sc}}$ even at the highest concentration of antibody. Images are 696 representative of three independent experiments. 
698 Figure 8. Time-course analysis of $\mathbf{m A b}$-induced prion clearance.

699 ScGT1 cells were incubated for 1 week with $5 \mu \mathrm{g} / \mathrm{mL}$ of mAbs. Untreated cells were used as negative 700 control (NC). After the initial treatment, cells were split and cultured in absence of mAbs for 1 month.

701 Cell lysates were digested with proteinase $\mathrm{K}(\mathrm{PK}+$ lanes $)$ and $\mathrm{PrP}^{\mathrm{Sc}}$ was probed by Western blot using 702 Fab D18. PrPSc levels were analyzed after one $(1 \mathrm{w})$, two $(2 \mathrm{w})$, three $(3 \mathrm{w})$ and four $(4 \mathrm{w})$ weeks after 703 the treatment to evaluate the stability of clearance during time. Prions were not detectable in treated 704 cells one month after the mAbs incubation. Just a slight signal from $\mathrm{PrP}^{\mathrm{Sc}}$ was found in EB8 treated 705 ScGT1 cells. Images are representative of three independent experiments. Lanes were run on the same 706 gel but were non-contiguous (white lines).

708 Figure 9. Effects of mAb treatment on ERK phosphorylation in GT1 cell line.

709 Infected and non-infected GT1 cells were treated with the different mAbs $(5 \mu \mathrm{g} / \mathrm{mL})$ for 6 days.

710 Cytosolic proteins were extracted and the levels of the phosphorylated form of ERK 1/2 complex

711 (pERK1/2) were probed by Western blot. The total amount of ERK (totERK1/2) was determined as

712 internal control. The treatment with DE10, DC2 and EB8 mAbs but not EF2 induces a significant

713 increase of phospho-ERK levels in ScGT1 compared to untreated cells. The same treatment shows no

714 effect on GT1 cells. Only the cells incubated with DC2 exhibit a significant decrease in the levels of

715 phospho-ERK. Statistics were performed using Student's T-test on a set of three experiments; data

716 were normalized on the total amount of ERK. * $\mathrm{P}<0.05$, ** $\mathrm{P}<0.01$ versus untreated controls both for 717 infected and non-infected cells. 


\section{1}

Epitope mapping of mAbs through direct binding.

Synthesized peptides from HuPrP (1 to 11) and MoPrP (12 to15) were coated to the microplates at concentration $2 \mu \mathrm{g} / \mathrm{mL}$. A detailed description of the peptides used in this assay is provided in Supplemental Figure S2. The four monoclonal antibodies DE10, DC2, EB8 and EF2 were added in concentration $5 \mu \mathrm{g} / \mathrm{mL}$. Bars indicate binding of antibodies to peptides.
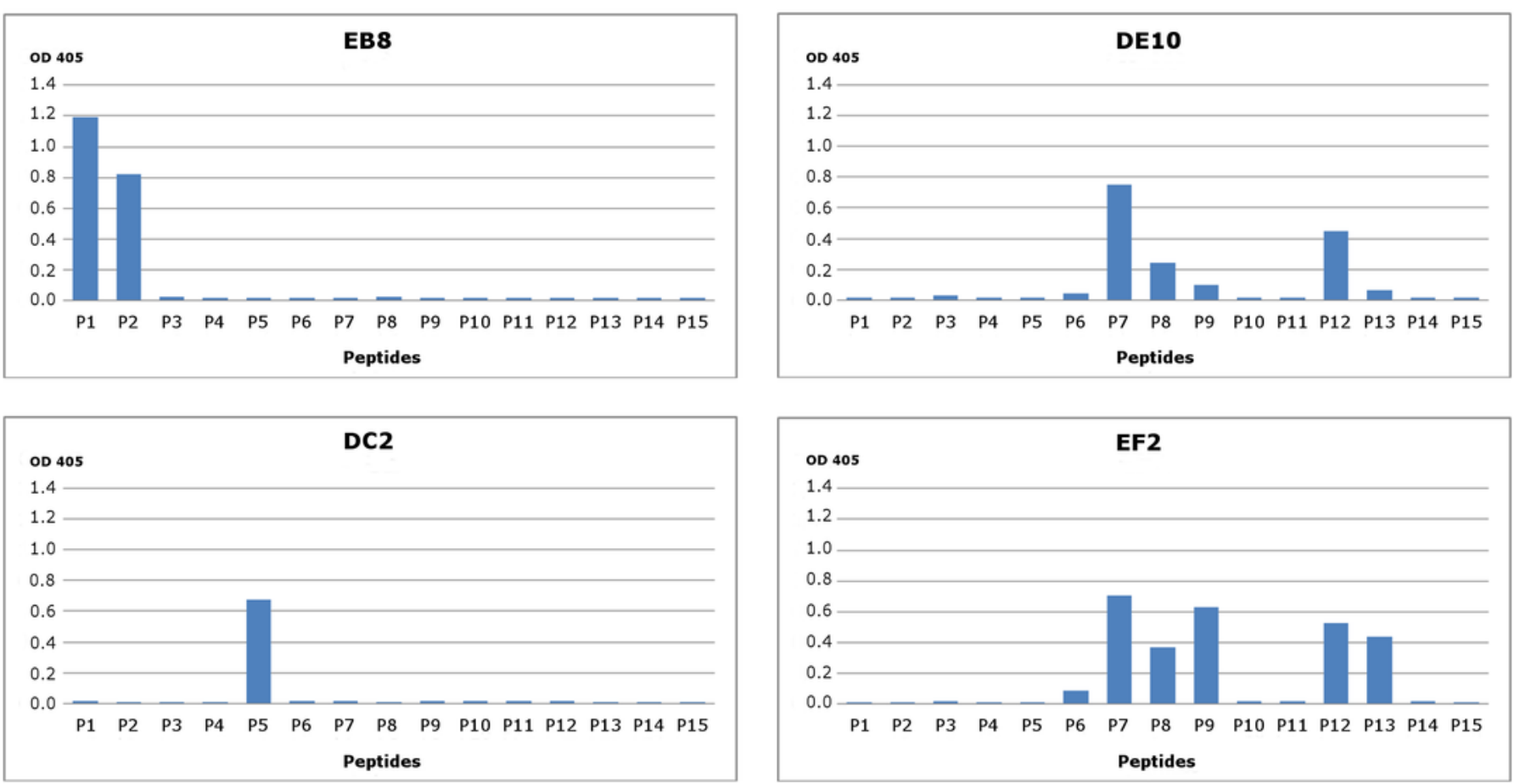
2

Epitope mapping of mAbs through competitive ELISA.

RecHuPrP ( $5 \mu \mathrm{g} / \mathrm{mL}$ ) was coated to 96 -well microtiter plate as antigen. Mixtures of the four monoclonal antibodies ( $1 \mu \mathrm{g} / \mathrm{mL}$ for EB8 and $0.2 \mu \mathrm{g} / \mathrm{mL}$ for the others) and synthesized peptides from HuPrP (1 to 11 ) and MoPrP (12 to 15$)(0.8 \mu \mathrm{g} / \mathrm{mL}$ ) were added. A detailed description of the peptides used in this assay is provided in Supplemental Figure S2. Bars indicate inhibition of monoclonal antibodies' binding.
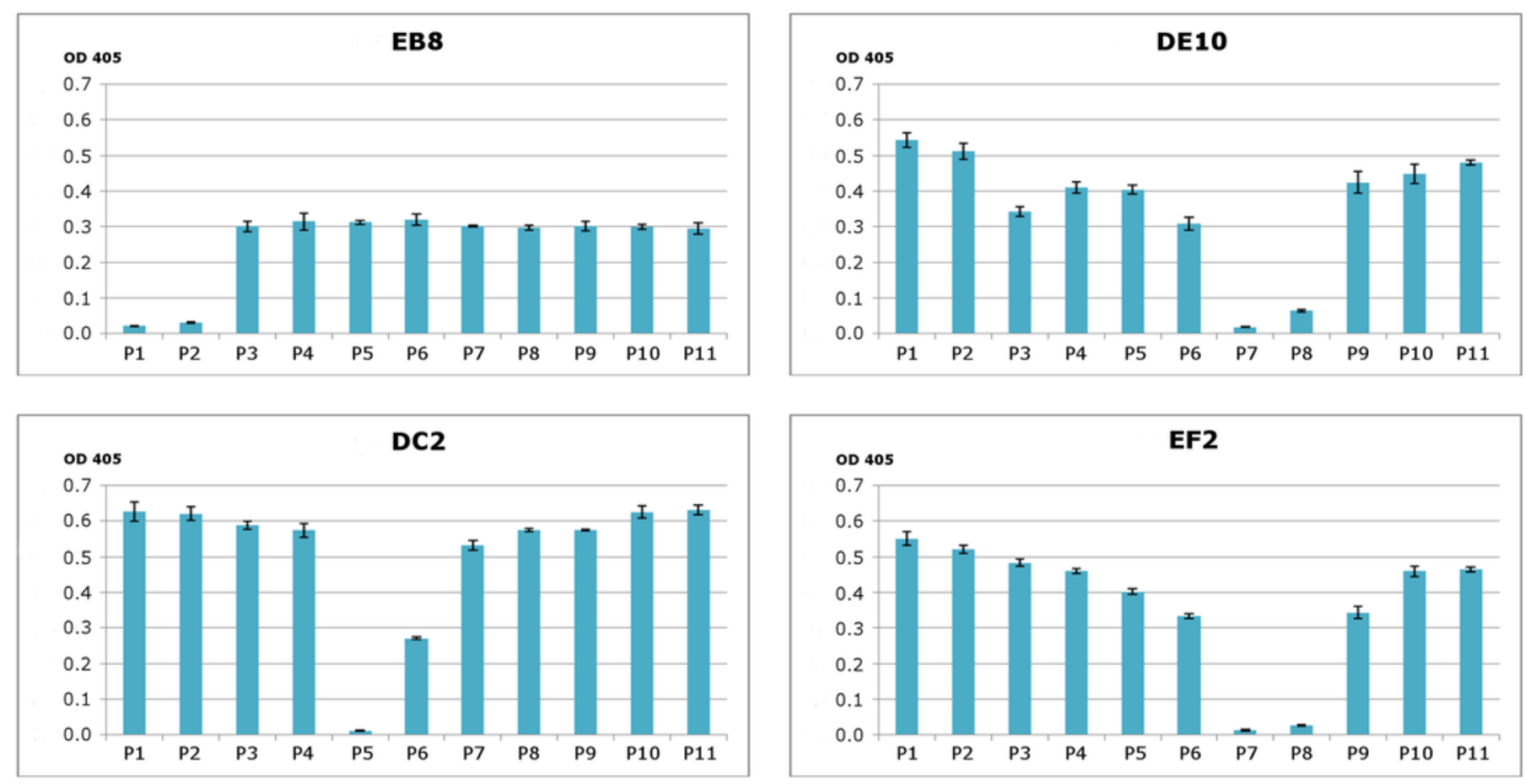
Suggested epitopes for the four monoclonal antibodies based on direct mapping and competitive ELISA essay.

The epitopes recognized by the 4 four mAbs (26-34aa for EB8; 35-46aa for DC2; 44-52aa for DE10 and 47-52 for EF2) are highlighted in a multi-alignment among the amino acidic $\mathrm{N}$ terminal sequences of mature PrP from the following species: human (Homo sapiens; P04156), mouse (Mus musculus; P04925), golden hamster (Mesocricetus auratus; P04273), sheep (Ovis aries; P23907), cow (Bos taurus; P10279), red deer (Cervus elaphus; P67987), rat (Rattus norvegicus; P13852) and rabbit (Oryctolagus cuniculus; Q95211).

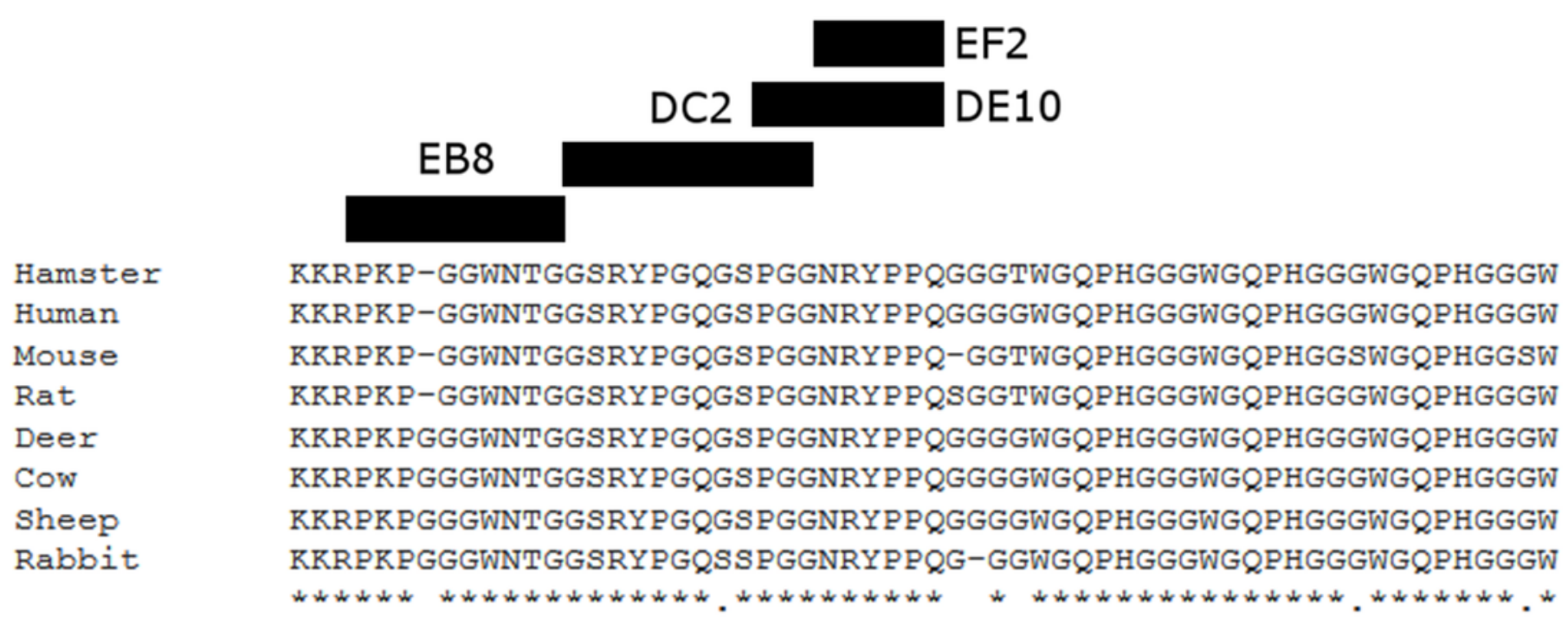


4

Immunoreactivity of mAbs probed by Western blot.

Homogenates from human (Hu), bovine (Bo), hamster (Ha), sheep (Sh), deer (De), rabbit (Ra), rat (Rat), mouse (Mo) and Prnp ${ }^{0 / 0}$ mouse (koMo) brain tissues were analyzed by Western blot using the four monoclonal antibodies. Different pattern of detection were observed. Samples from human, hamster, rat and mouse tissues were consistently detected by all the mAbs while bovine, sheep, deer and rabbit samples were poorly recognized by the EB8 antibody. Rabbit PrP was not detected by DC2 antibody. Non-contiguous lanes are highlighted (white lines).

Bo Hu Ha Sh De Ra Rat Mo koMo

$37 \mathrm{kDa}$

EB8

$25 \mathrm{kDa}$

$37 \mathrm{kDa}$

DC2 $25 \mathrm{kDa}$

$37 \mathrm{kDa}$

EF2 $25 \mathrm{kDa}$

$37 \mathrm{kDa}$

DE $1025 \mathrm{kDa}$ 


\section{5}

Immunolocalization of PrP in GT1 cells.

GT1 (panel A) and ScGT1 (panel B) cells were fixed with PFA and PrP was immunostained with the four mAbs (in green) as detailed in Materials and Methods. Nuclei were counterstained with DAPI (in blue). On the left of each panel merged images are shown. All the antibodies show a similar pattern. The cell membrane and the perinuclear region are stained. No difference was observed after guanidinium treatment. Images are representative of at least three coverslips. Scale bars, $20 \mu \mathrm{m}$. 

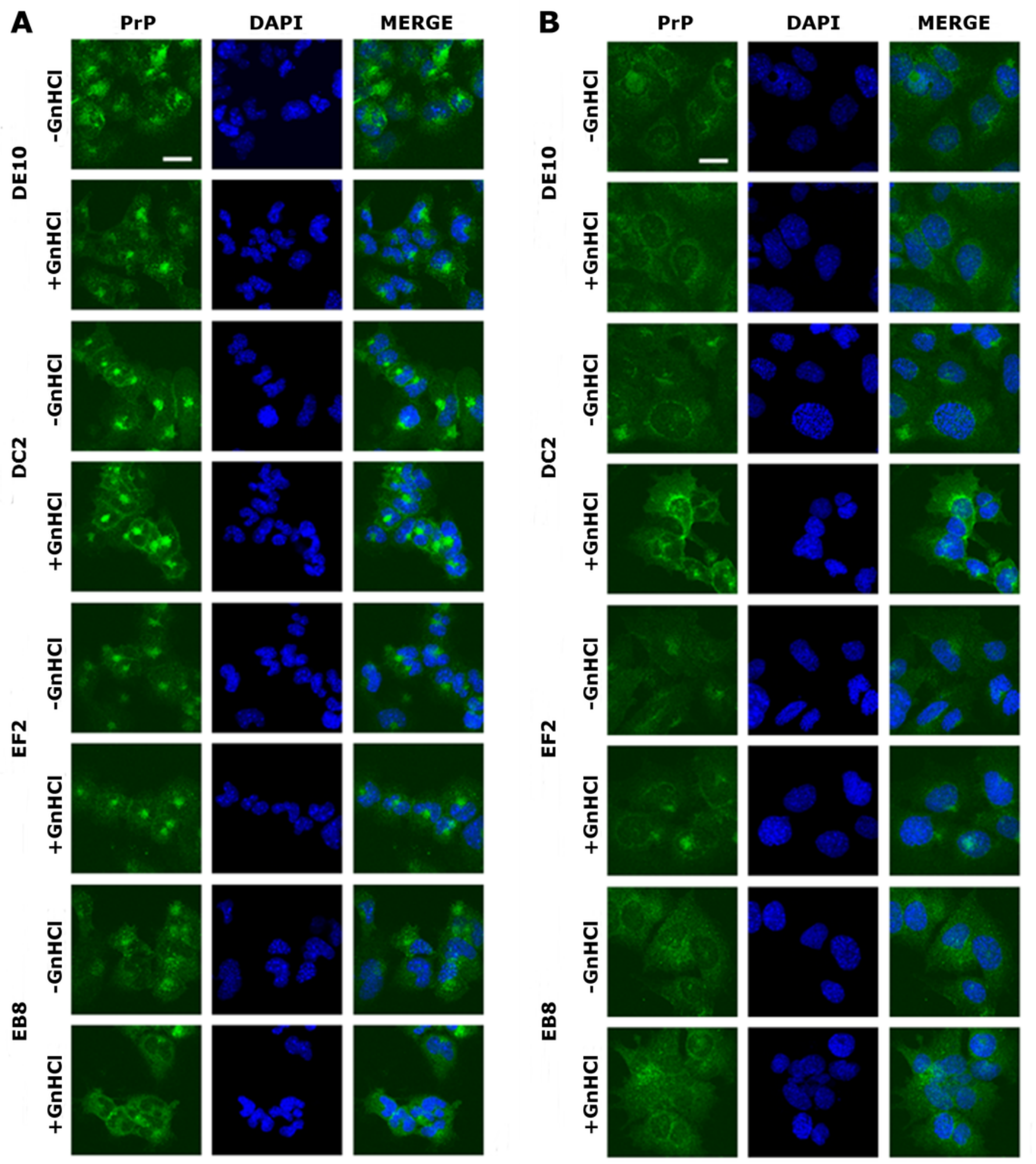


\section{6}

Immunohistochemistry on human tissue samples.

Immunohistochemistry of $\mathrm{PrP}^{\mathrm{Sc}}$ deposits in the cerebellum of a SCJD patient (upper four figures) and of a non-CJD control (lower four figures). Immunolabeling was performed with 5 $\mu \mathrm{g} / \mathrm{mL}$ of mAbs EB8, DC2, DE10 or EF2, respectively. Magnified: $200 \mathrm{x}$.

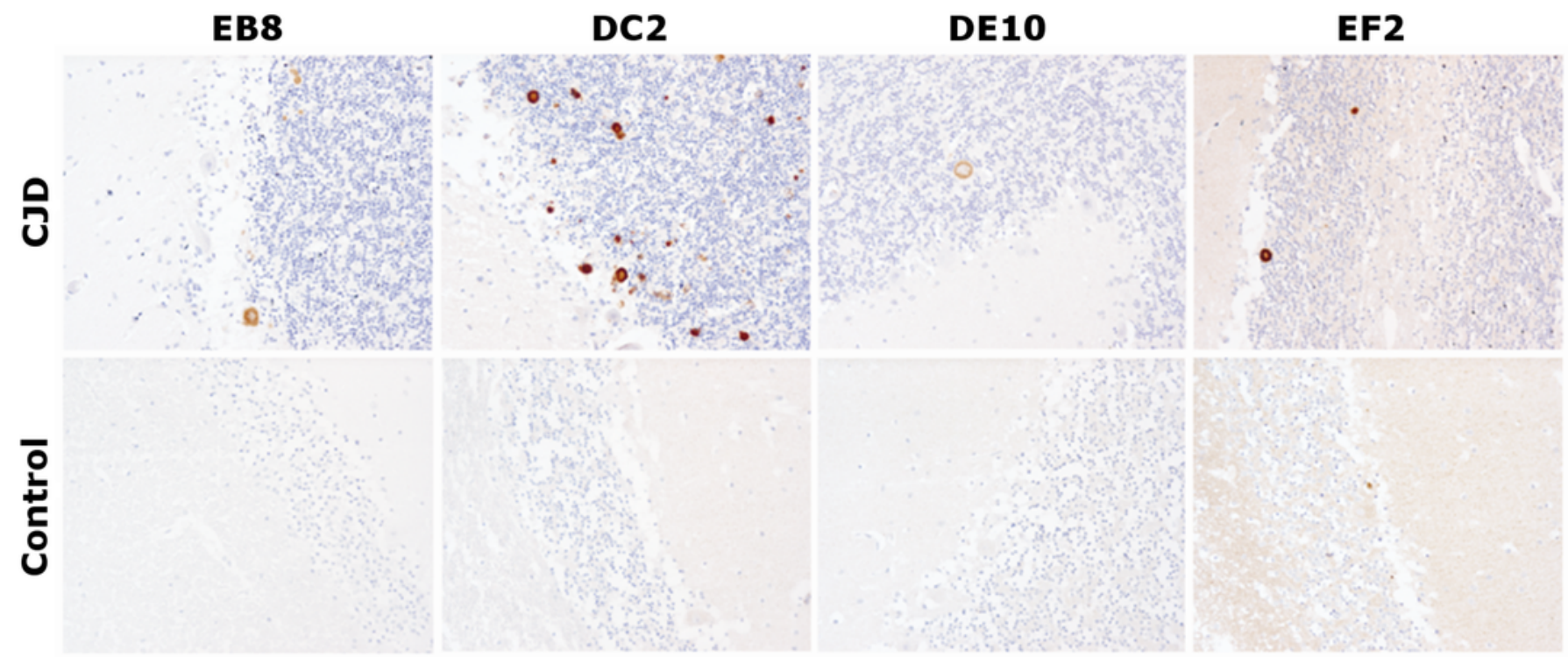




\section{7}

$\mathrm{N}$-terminal mAbs can inhibit prion replication.

RML infected GT1 cells were treated for 6 days with increasing concentrations (0, 1, 2.5, 5 and $7.5 \mu \mathrm{g} / \mathrm{mL}$ ) of EB8, DE10, DC2 and EF2 mAbs, refreshing medium the third day. Cell lysate were digested with proteinase K (PK + lanes) and PrPsc levels checked by Western blot using Fab D18 for detection. As positive control (PC) cell lysates from uninfected GT1 cells were also digested. About $25 \mu \mathrm{g}$ of total protein were loaded as control (PK - lanes). DE10, DC2 and EF2 mAbs promoted a complete clearance of prions starting from the lowest concentration tested whilst cells treated with EB8 showed a residual signal of $\mathrm{PrP}^{\mathrm{PC}}$ even at the highest concentration of antibody. Images are representative of three independent experiments. 

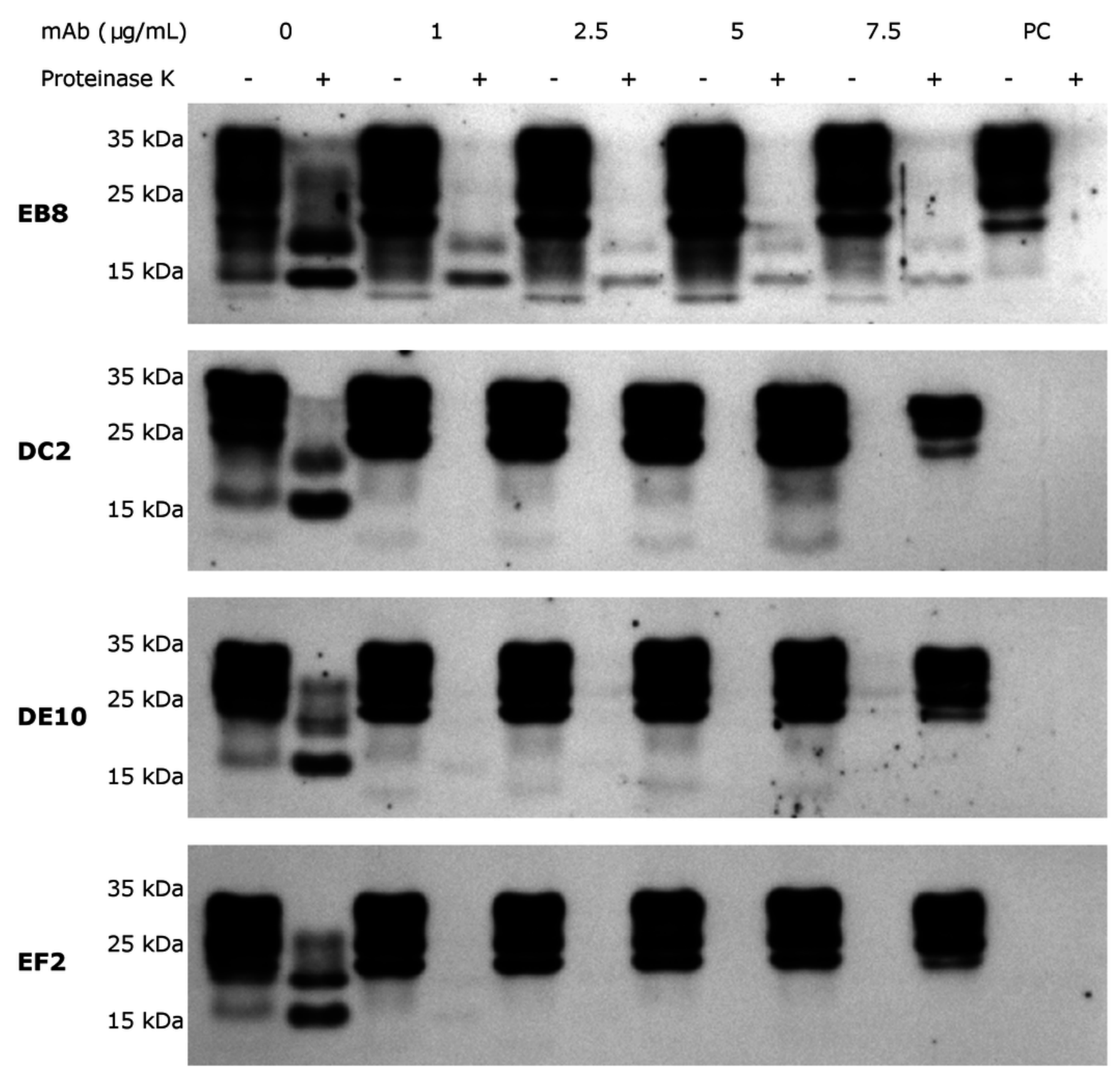
8

Time-course analysis of mAb-induced prion clearance.

ScGT1 cells were incubated for 1 week with $5 \mu \mathrm{g} / \mathrm{mL}$ of mAbs. Untreated cells were used as negative control (NC). After the initial treatment, cells were split and cultured in absence of mAbs for 1 month. Cell lysates were digested with proteinase K (PK + lanes) and PrPsc was probed by Western blot using Fab D18. PrPsc levels were analyzed after one (1 w), two (2 w), three ( $3 \mathrm{w}$ ) and four ( $4 \mathrm{w}$ ) weeks after the treatment to evaluate the stability of clearance during time. Prions were not detectable in treated cells one month after the mAbs incubation. Just a slight signal from PrPsc was found in EB8 treated ScGT1 cells. Images are representative of three independent experiments. Lanes were run on the same gel but were non-contiguous (white lines). 
$\mathrm{mAb}$

NC

EB8

DE10

NC

DC2

EF2
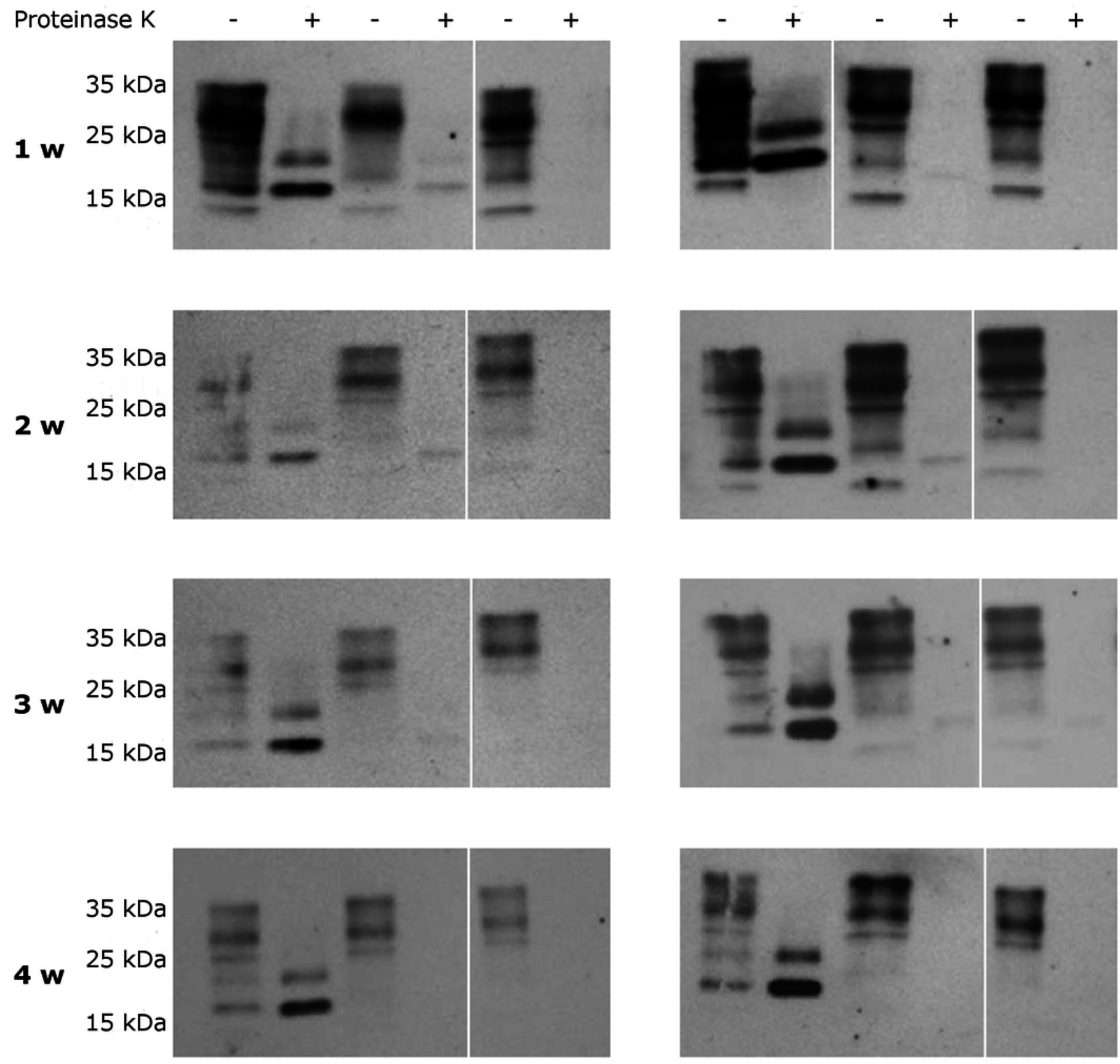


\section{9}

Effects of mAb treatment on ERK phosphorylation in GT1 cell line.

Infected and non-infected GT1 cells were treated with the different $\mathrm{mAbs}(5 \mu \mathrm{g} / \mathrm{mL})$ for 6 days. Cytosolic proteins were extracted and the levels of the phosphorylated form of ERK 1/2 complex (pERK1/2) were probed by Western blot. The total amount of ERK (totERK1/2) was determined as internal control. The treatment with DE10, DC2 and EB8 mAbs but not EF2 induces a significant increase of phospho-ERK levels in ScGT1 compared to untreated cells. The same treatment shows no effect on GT1 cells. Only the cells incubated with DC2 exhibit a significant decrease in the levels of phospho-ERK. Statistics were performed using Student's T-test on a set of three experiments; data were normalized on the total amount of ERK. $* P<0.05, * * P<0.01$ versus untreated controls both for infected and non-infected cells.
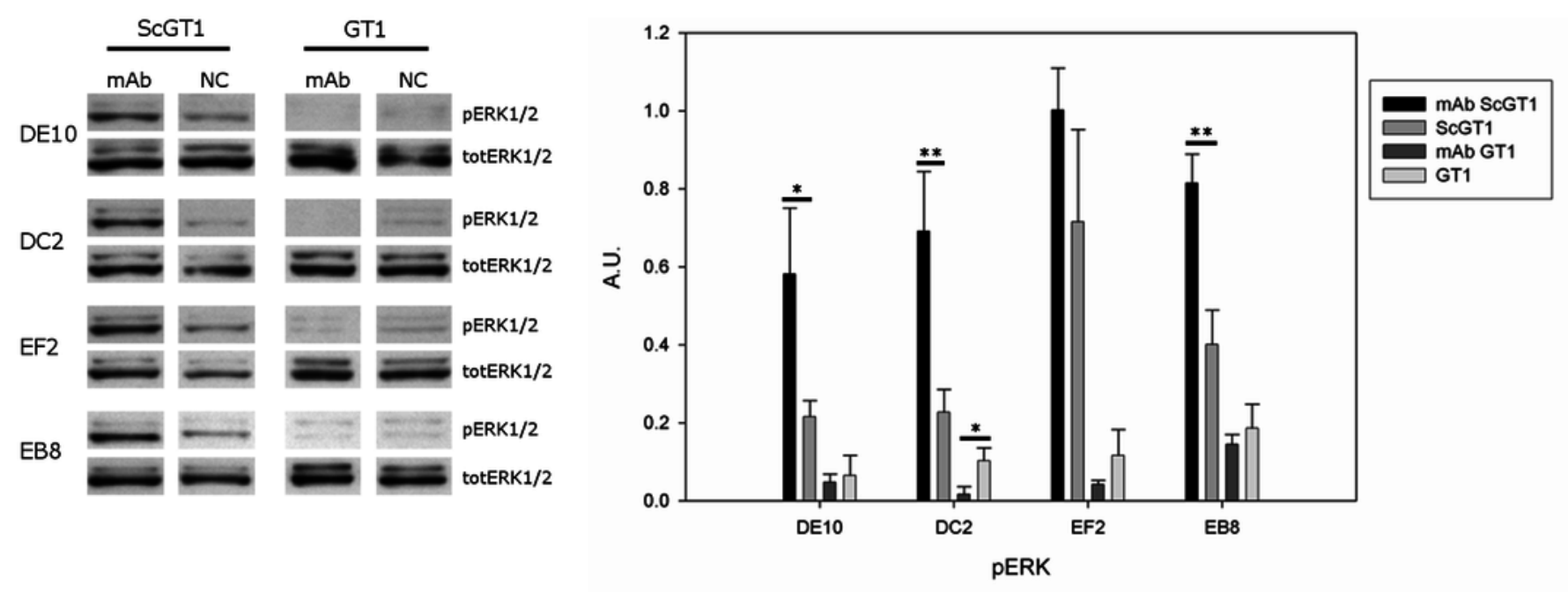


\section{Table 1 (on next page)}

Affinity constants $\left(K_{D}\right)$ of mAbs for recombinant mouse PrP (recMoPrP) as probed by surface plasmon resonance (SPR) assays. 


\begin{tabular}{|l|l|}
\hline $\mathbf{m A b}$ & $\mathbf{K}_{\mathbf{D}} \mathbf{( M )}$ \\
\hline EB8 & $1.714 \times 10^{-8}$ \\
\hline DC2 & $6.144 \times 10^{-10}$ \\
\hline EF2 & $3.084 \times 10^{-9}$ \\
\hline DE10 & $1.071 \times 10^{-8}$ \\
\hline
\end{tabular}

